УДК 323.39(477.83)"1990/2019"

DOI: https://doi.org/10.31470/2518-7600-2021-13-257-290

REGIONAL POLITICAL ELITE OF LVIV REGION: FEATURES OF FORMATION (1990-2019)

\title{
РЕГІОНАЛЬНА ПОЛІТИЧНА ЕЛІТА ЛЬВІВЩИНИ: ОСОБЛИВОСТІ СТАНОВЛЕННЯ (1990-2019 РР.)
}

\section{РЕГИОНАЛЬНАЯ ПОЛИТИЧЕСКАЯ ЭЛИТА ЛЬВОВЩИНЫ: ОСОБЕННОСТИ СТАНОВЛЕНИЯ (1990-2019 ГГ.)}

\section{Аліна Ясінська,}

кандидат політичних наук, науковий співробітник

відділу соціально-політичної історії

AlinaYassinska@ukr.net

ID ORCID: 0000-0001-6056$034 \mathrm{X}$

Інститут політичних i

етнонаціональних

досліджень ім. І.Ф. Кураса НАНУ

вул. Генерала Алмазова, 8, м. Київ, Україна, 01011
Alina Iasinska, Ph.D. in Political sciences, Researcher Department of Socio-Political History AlinaYassinska@ukr.net ID ORCID: 0000-0001-6056$034 \mathrm{X}$

National Academy of Sciences of Ukraine Kuras Institute of Political and Ethnic Studies street General Almazov, 8, Kyiv, Ukraine, 01011

\section{ABSTRACT}

The article examines the peculiarities of the formation of the regional political elite of Lviv region in the period from 1990 to 2019. The main attention is focused on three tasks: who should be referred to the category of "political elite» of Lviv region; what are the main ways of its formation, starting from the period of formation of Ukraine as a state to the present stage; what is the quantitative assessment of the political elite of Lviv region. 
In particular, it was determined who should be considered the political elite of the region. Using the method of positional analysis used in the study, the regional political elite was classified into formal and informal. It is determined that the formal political elite holds certain positions in the power vertical, which formalizes its involvement in political decision-making. Instead, the informal elite is represented by individuals who, without holding leadership positions, form a certain type of relationship with the masses, play an important role in important decision-making and influence the exercise of political power in the region through their resources (financial capital, authority, access to the formation of public opinion and its manipulation, etc.).

The process of renewal of Lviv's formal political elite since 1990 was analyzed and it was found that it was during this period that the embryos of democratic processes and the transition to multiparty system were observed in the region. It was noticed that quite often the regional political elite of Lviv region used the representative bodies of the region as a starting point for further career growth, which led to a constant movement and influx of new faces.

It has been studied that among the informal political elite, the most powerful group can be considered the business elite, which in addition to financial levers of influence often uses the manipulation of public opinion through access to media resources. It is noted that the renewal in this group of elites is much slower than among the formal political elite.

Separately, it is a quantitative assessment of the regional political elite of Lviv region. As it is difficult to talk about specific quantitative calculations, it is noted that this category includes both a relatively small cohort of people (from several hundred) who control most of the resources and established strong ties at the regional and national levels, and significantly expand it the number of people (up to one thousand two hundred), including the most influential politicians (MPs of Ukraine), heads and deputies of local councils, the leadership of the regional state administration and its 
departments, heads of regional organizations of political parties and major informal leaders in the region.

Keywords: regional political elite, people's deputies, Lviv Regional State Administration, Lviv Regional Council, Lviv City Council, political parties, business elite, media resources.

Постановка проблеми. Актуальність теми. Метою існування будь-якої держави є створення необхідних умов для самореалізації людини та народу, завдання яких, у свою чергу, полягає у розбудові та розвитку власної держави. Побудова національної держави вимагає чималих зусиль та взаємодії поміж собою усіх суспільних груп. Як правило, суспільство делегує місію державотворення, так званим, провідникам, які демонструють достатню кількість якостей для того, щоб втрутитися в цей процес, виробити відповідну ідеологію та стратегію функціонування національної держави.

Кожним суспільством завжди керує еліта, незалежно від класового поділу чи існуючих у ньому економічних структур. У класичному розумінні політичною елітою можна вважати сукупність осіб, які займають ключові позиції в структурі влади або ж осіб, які наділені владою та в той чи інший спосіб впливають на прийняття політичних рішень. Міждисциплінарний характер досліджень політичної еліти пов'язаний з тим фактом, що окремі теорії еліт трактують це явище по різному, виходячи з відмінних теоретичних та методологічних парадигм, характерних для певних наукових дисциплін. У результаті, виникає велика різноманітність тлумачення механізмів функціонування еліт, способів їх визначення та виокремлення, а також особливостей iї структури та зв'язків поміж основними елементами.

Зростання значення місцевого самоврядування та реформа децентралізації посприяли ще більшому зацікавленню регіональною елітою. Оскільки явище політичної еліти в Україні $є$ недостатньо дослідженим, а в регіональному контексті ще й досить різновекторним та багатогранним, 
проблема потребує комплексного дослідження, що видається можливим завдяки вирішенню низки завдань.

Аналіз останніх досліджень та публікацій. Наукові розвідки, присвячені дослідженню регіональної політичної еліти Львівщини висвітлені у працях таких науковців: В. Маркітантова (у науковому доробку дослідника знаходимо статті, в яких автор розкрив поведінкові аспекти представників регіональної політичної еліти Львівщини та Хмельниччини під час виборчих кампаній, окреслив тенденції розвитку політикуму Львівщини, проаналізував представництво львівської регіональної еліти у Верховній Раді України тощо), В. Яремчука (розглядав специфіку львівської політичної еліти крізь призму регіонального політичногорежиму на Львівщині), О. Куцової (у статті авторки міститься інформація щодо етапів становлення львівської регіональної політичної еліти), Л. Харченко (стаття якої була присвячена політичній культурі львівської регіональної політичної еліти), Р. Рака, Ю. Лобана тощо.

Метою статті $€$ вивчення особливостей становлення регіональної політичної еліти Львівщини (1990-2019рр.). Для досягнення окресленої мети поставлено наступні дослідницькі завдання: a) визначити, хто відноситься до категорії «політичної еліти» у Львівській області; б) проаналізувати шляхи формування регіональної політичної еліти Львівщини, починаючи з періоду становлення України як держави і до сучасного етапу; в) дати кількісну оцінку політичної еліти Львівщини.

Отже, до політичної еліти ми відносимо осіб, які або наділені владою приймати політичні рішення, або ж через наявні ресурси впливають на їх прийняття. Виходячи з методу позиційного аналізу, зазначимо, що наявність певної посади у владній вертикалі формалізує причетність до прийняття політичних рішень, а відтак дозволяє виділити категорію формальної еліти. До якої віднесемо обраних (народні депутати України; голови та депутати обласних, міських, районних рад 
тощо) та призначених (очільники обласних державних адміністрацій, їхні заступники, тимчасово виконуючі обов'язки голів обласних державних адміністрацій; керівники структурних підрозділів; голови районних державних адміністрацій тощо) представників політичної еліти, які офіційно представляють область на регіональному та загальнодержавному рівнях. Іншу категорію політичної еліти формують особи, які хоч і не займають керівних посад, однак завдяки ресурсам (фінансовий капітал, авторитет, доступ до формування суспільної думки та маніпулювання нею, родинні зв'язки, спільні бізнес-інтереси тощо), якими вони володіють, формують певний тип відносин з масами, посідають вагоме місце у процесі прийняття важливих рішень та впливають на здійснення політичної влади (сюди відносимо представників майнових кланів, бізнес та медійного середовища, організованої злочинності тощо).

Отже, першою категорією формальної еліти, яку ми розглянемо будуть депутати Верховної Ради України, які обиралися в одномандатних виборчих округах Львівщини (кількість виборчих округів зазнала значних змін: у 1990 р. їх було 24, починаючи з 1998 р. - 12, з яких чотири включали у себе частини обласного центру - міста Львова), а також за виборчими списками політичних партій та виборчих блоків політичних партій у загальнодержавному багатомандатному виборчому окрузі.

У результаті виборів 1990 р. до Верховної Ради України було обрано 25 народних депутатів від Львівської області. Хоча за партійною належністю склад представників областей у Верховній Раді України не вирізнявся різноманітністю (оскільки переважна більшість новообраних депутатів були членами панівної тоді Комуністичної партії України) Львівську область представляли лише 7 осіб (28\%), які були членами Комуністичної партії України, решта - були позапартійними депутатами, серед яких більшість належала до політичної партії «Народний рух України» (Народні Депутати України 1го скликання (1990-1994). Верховна Рада України.). 
На наступних виборах 1994 р. (уже багатопартійних) від Львівської області було обрано 22 народних депутати, серед яких 12 осіб були представниками різних політичних сил (тобто частково відображалася тенденція переходу до багатопартійності), однак найбільше депутатів з Львівської області все ж були членами НРУ (5 депутатів) (Народні депутати України 2-го скликання (1994-1998)). Значні чисельні зміни (кількість депутатів значно зменшилася) відбулися під час виборів 1998 р., які проходили за змішаною виборчою системою. Тоді до Верховної Ради України було обрано лише 13 депутатів-мажоритарників. Найбільшу групу, як і раніше, становили депутати від НРУ (5 осіб) (Народні Депутати України 3-го скликання (1998-2002)). Щодо партійного представництва, то ситуація дещо змінилася уже після виборів 2002 р., саме тоді НРУ у Львівській області почав втрачати свої домінуючі позиції, натомість популярності набула політична партія «Реформи і порядок» (ПРП).

Спостерігаємо, що тенденція щодо кількості депутатівмажоритарників від Львівщини у парламенті збереглася і на виборах 2012 р. (область представляли 12 осіб), однак, щодо партійного представництва, то єдиними представленими партіями від Львівської області були ВО «Батьківщина» та ВО «Свобода» (по 4 особи) (Народні депутати України). Зазначимо, що повернення у 2012 р. до змішаної виборчої системи призвело до значного зростання відсотка оновлення представників від Львівської області у Верховній Раді України, що разом зі змінами спектру представлених у парламенті політичних сил свідчило про значну динаміку в формуванні політичної еліти регіону. Підтвердженням може слугувати ще й те, що політичні симпатії населення Львівщини були чітко сформовані в ході виборчої кампанії, а представники місцевої політичної еліти, виходячи на загальнодержавний рівень, підтримували конкретну партійну ідеологію, не виявляючи свою прихильність інертно популярним політичним силам. 
Суттєві зміни в електоральних симпатіях виборців відбулися під час виборів 2019 р. По - перше, Львівська область (раніше, як найбільш активна в електоральному плані) продемонструвала досить низьку явку на парламентських виборах $(53,4 \%)$, а подолати 5\% виборчий бар'єр та зберегти свій попередній результат зуміли лише дві партії з виборів 2014 р. (БПП «Солідарність» (20,4\% і 19,8\% відповідно) і ВО «Свобода» (6,2\% і 5,5\% відповідно)). Решта політичних сил були новими партіями, серед яких найвищим показником відзначилася новостворена партія «Голос» $(23,09 \%)$ (Радь, 2019). По - друге, лише 5 з 12 депутатів-мажоритарників були переобрані повторно під час парламентських виборів 2019 р. Йдеться про М. Бондара (Який балотувався у 2014 р. від політичної партії «Народний фронт», а у 2019 р. - від партії «Європейська Солідарність»), Я. Дубневича (у 2014 р. - від партії БПП «Солідарність», а у 2019 р. - як самовисуванець), Т. Батенка (у 2014 р. - від партії БПП «Солідарність», а у 2019 р. - як самовисуванець), А. Лопушанського (обидва рази балотувався як самовисуванець) i А. Кота (у 2014 р. балотувався від БПП «Солідарність», а у 2019 р. - як самовисуванець) (Радь, 2019). Свої позиції в області дещо втратила БПП «Солідарність» порівняно з виборами 2014 р. Якщо у 2014 р. від БПП «Солідарність» на мажоритарці перемогли п'ять кандидатів (Радь, 2019), то у 2019 р. їх кількість скоротилася до двох. Однак, в цілому, депутатський корпус від Львівщини у складі Верховної Ради України IX скликання i надалі залишився досить багато чисельним, йдеться про 30 представників від області. Причому, абсолютна більшість із них обиралися вперше та лише 9 депутатів представляли Львівщину у парламенті попереднього скликання. За результатами виборів політична партія «Слуга народу» провела до парламенту 9 вихідців із Львівщини, партія «Свропейська солідарність»-7, партія «Голос»-6, партія ВО «Батьківщина» - 2 та ще 6 депутатів, які балотувалися від інших партій (Тузяк, 2019). 
Відслідковуючи показники оновлення рад різного рівня Львівської області, зазначимо, що уже в 1990 р. відбулася значна зміна депутатського складу рад Львівщини, що разом 3 іншими показниками дає змогу вважати ці вибори порівняно демократичними. Так, Львівська обласна рада була оновлена на 95\% у 1990 р., на 85\% у 1998 р., на 74,2\% у 2006 р. (Маркітантов, 2009) та на 77 \% (за нашими підрахунками) у 2015 р. (Чергові місцеві вибори 25 жовтня 2015 р.). За результатами чергових місцевих виборів 2015 р. до Львівської обласної ради VII скликання пройшли 84 депутати, що майже вдвічі менше, ніж було у попередніх скликаннях. Політична еліта обласної ради суттєво оновилася, оскільки до ради увійшли лікарі, вчителі та бійці АТО. Найбільшу фракцію сформували депутати від партії БПП «Солідарність» (20 депутатів), наступні за чисельністю фракції політичної партії «Об’єднання «Самопоміч» (13 депутатів), ВО «Батьківщина» (8 представників), політичної партії «Громадянська позиція» 7 депутатів, наступними були партії: «УКРОП», Радикальна партія Олега Ляшка, «Громадський рух «Народний контроль», Народний рух України (НРУ), які отримали по 5 мандатів (Хто став депутатами Львівської обласної ради VII скликання). Однак ситуація з більшістю в раді за час поточної каденції змінювалася тричі. Остання зміна відбулася у 2019 р. після невдалої спроби В. Гірняка усунути з посади голови ради О. Ганущина. Тоді замість А. Білоуса першим заступником було обрано представника політичної партії «Об’єднання «Самопоміч» I. Собко (без згоди партії), а замість В. Гірняка заступником став представник НРУ Б. Гагалюк. Таким чином, більшість в обласній раді в черговий раз переформатувалась (45 депутатів), куди увійшли, крім БПП «Солідарність», ВО «Батьківщина» і НРУ, також фракції УКРОП, Радикальна партія Олега Ляшка і позафракційні депутати (Радь, 2019).

Достатньо поширеною тенденцією в 2019 р. для Львівщини стала зміна структурування обласної ради (зокрема, вихід депутатів із фракцій), що було викликано 
розходженням позиції депутатів з позицією фракції. Так, у Львівській обласній раді було виключено з фракцій 5 депутатів 3 Радикальної партії Олега Ляшка, політичної партії «Об'єднання «Самопоміч» та з партії «Громадянська позиція» (Радь, 2019).

Щодо процесу оновлення Львівської міської ради, зазначимо, що кількісні показники увесь час коливалися, однак завжди були досить високими. Так, в 1994 р. рівень оновлення ради становив 84\%, у 1998 р. - 83,3\%, дещо знизився в 2002 р. -61,1\% , в 2006 р. становив 70\% (Маркітантов, 2009) та знову зріс й становив 83,1\% (Інформаційний портал депутатів Львівської міської ради) (за нашими підрахунками) у 2015 р. Реальною владою у прийнятті рішень у Львівській міській раді VI скликання серед 11 представлених у ній політичних сил були наділені представники ВО «Свобода». Депутатів цієї політичної сили налічувалося 55 із 90 депутатів міської ради.

На думку експертів Громадянської мережі ОПОРА, у раді тогочасного скликання були авторитетні чиновники, за порадою до яких зверталися однопартійці та за вказівкою яких приймалися ті чи інші рішення. Серед таких варто виділити Ю. Михальчишина, А. Хомицького, Р. Плахтія, О. Махніцького (Львівська міська рада: хто в домі господар?), які були кураторами у вирішенні ідеологічних, соціально-економічних та питань у сфері комунального майна та власності.

Певним політичним феноменом львівської регіональної політичної еліти став незмінний з 2006 р. голова міської ради Львова А. Садовий, якого тричі поспіль переобирали на цю посаду (2006 р., 2010 р., 2015 р.). А. Садовий* відомий,

А. Садовий закінчив Національний Університет «Львівська політехніка», НАДУ при Президентові України за фахом «державне управління», а також Львівський технікум радіоелектроніки. Кар'єра А. Садового розвивалася досить стрімко та була багатовекторною. Так, у 1992-1995 рр. А. Садовий працював заступником директора Львівського відділення Фонду соціальної адаптації молоді при Кабінеті Міністрів України. У 1993 р. разом з колегами заснував у Львові радіостанцію «Люкс». 1995-1998 рр. був членом наглядової ради ЗАТ ІК «Галицькі інвестиції», а у 1997-2005 рр. обіймав посаду голови ради та голови правління ВАТ «Південьзахіделектромережбуд». 32002 до 2006 року був головою ради ЗАТ 
насамперед, як засновник спершу громадської організації, а потім - і політичної партії «Об’єднання «Самопоміч», співзасновник ТРК «Люкс» (1993р.) (Хто керував Львовом упродовж останніх 28 років: ретроспектива).

Політик відзначався власним політичним баченням щодо ситуації як в області, так і в країні загалом, що пізніше вплинуло на стосунки мера Львова та президента П. Порошенка. Неодноразово, упродовж 2014-2015 рp., А. Садовому робили пропозиції побудувати політичну кар'єру в столиці (зокрема, йшлося про посаду віце-прем'єр-міністра з регіональної політики в уряді А. Яценюка та навіть Прем'єрміністра України) (Гройсману крісло віце-прем'єра запропонували після того, як від нього відмовився Садовий; П'єцух, 2016), однак політик від них відмовився. Позицію вичікування А. Садового можна було розцінювати як стратегію, яка могла йому дозволити залишитися у великій політиці, уникаючи ризиків зниження свого рейтингу в умовах політичної та соціально-економічної нестабільності (Яремчук, 2018). Про наявність стратегії свідчать також рейтинг та результати політичної партії «Об’єднання «Самопоміч». Йдеться про високий рівень підтримки партії на позачергових виборах до Верховної Ради України в жовтні 2014 р. (партія стала ефективним каналом рекрутування політичної еліти). Тоді політична сила здобула 10,9\% голосів виборців, ставши третьою за чисельністю депутатською фракцією, та перетворилася 3 партії регіонального рівня на партію загальнодержавного. Політична сила перетнула 5\% виборчий рубіж у 24 регіонах України, а найвищу підтримку отримала у Києві (21,4\% голосів) та у Львівській області (18,8\%) (Позачергові вибори народних депутатів України, 2014).

«Телерадіокомпанія «Люкс». 31998 до 2002 року - депутат Львівської міської ради, був головою комісії з питань економічної політики. У 2000 р. балотувався на проміжних виборах до Верховної Ради по 115 округу (м. Львів) як самовисуванець, а у 2002 р. - на посаду Львівського міського голови як самовисуванець. У 2004 р. ініціював створення громадського об'єднання «Самопоміч» (Садовий Андрій Іванович. Львівська міська рада - голова 6, РХП, Міський голова Львова). 
Географія політичних симпатій населення Львівській області досить строката. Партія А. Садового часто перебувала в опозиції, зокрема, в обласній раді. Проте, якщо подивитися на політичну ситуацію в області загалом, помітно, що розклад сил у містах значно відрізнявся від ситуації в районних та сільських радах, де домінували представники колишньої партії влади - БПП «Солідарність», а також ВО «Свобода» і ВО «Батьківщина». Натомість наростаюче напруження між групами політичної еліти Львівщини (серед них - найбільш помітної на той час, пов'язаної з А. Садовим) і президентською вертикаллю влади посилило конкуренцію політичних партій на місцевих виборах. Внаслідок чого пропрезидентська партія БПП «СОЛІДАРНІСТЬ» стрімко почала втрачати вагу (як канал рекрутування регіональної політичної еліти), а значна частина висуванців взагалі прагнули відмовитися від вияву своєї партійної ідентифікації. Саме місцеві вибори 2015 р. продемонстрували зміну партійної належності та поведінки львівської регіональної політичної еліти. Так, на виборах міських голів області (йдеться про 9 міст обласного підпорядкування і 34 районного) більшість кандидатів обрали тактику на час виборчої кампанії не пов'язувати себе партійною належністю (19 міських голів). Політична партія «Об’ єднання «САМОПОМІЧ» (що підтверджувало їі вагомі позиції в області) як і провладна тоді БПП «Солідарність», здобули по 5 голів міст (Буковский, 2015).

Аналізуючи кадрову політику у Львівській обласній державній адміністрації, зазначимо, що особливо нестабільною вона була в період 3 квітня 2010 р. - до грудня 2014 р. За цей час головами Львівської обласної державної адміністрації були призначені (Президентами України В. Януковичем, П. Порошенком та в.о. Президента України О. Турчиновим) 8 осіб, серед яких найбільш скандальним було призначення О. Сала (жовтень 2013 р. - березень 2014 р.) - генерала МВС, проти якого після «помаранчевої революції» були відкриті кримінальні провадження щодо «перешкоджання здійсненню 
виборчого права 3 використанням службового становища» та «зловживання владою або службовим становищем», його було оголошено у міжнародний розшук після чого справи були припинені (Янукович призначив на Львівщину губернатора, якого шукали за фальсифікації.). Плутанина у призначеннях першої особи в області за період президентства В. Януковича була наслідком безпорадності влади утримати контроль над областю, включаючи і групи регіональної політичної еліти. Однак і після перемоги Революції Гідності кадрові призначення центральної влади на Львівщині не відзначалися послідовністю.

Події Свромайдану, безумовно, відобразилися на балансі політичних сил регіону. По-перше, відбулося цілковите усунення представників ПАРТІЇ РЕГІОНІВ 3 місцевих адміністрацій, органів місцевого самоврядування. По-друге, новопризначені керівники були представниками патріотично налаштованих політичних сил, що лише підсилило увагу до проблеми захисту країни від російської агресії та перетворило область на один із центрів волонтерства.

У кризовий для країни та області зокрема, час, головою Львівської обласної держадміністрації було призначено I. Cex, членкиню ВО «Свобода», яка відіграла значну роль у зміцненні позицій політичної сили в регіоні. Попри своє нетривале (березень-серпень 2014 р.) перебування на посаді голови облдержадміністрації, політикиня активно займалася підтримкою різноманітних оборонних проектів, опікувалася військовослужбовцями, їхніми родинами, переселенцями та волонтерством. Однак напередодні позачергових парламентських виборів їй все ж таки не вдалося уникнути критики, розмов про причетність до корупційних скандалів, що активно висвітлювалося в державних та регіональних 3MI, результатом чого стало іiі звільнення 3 посади за власним бажанням. Її наступником став Ю. Турянський**, за каденції

** Ю. Турянський був призначений як тимчасово виконуючий обов'язки голови Львівської облдержадміністрації та перебував на посаді з серпня по грудень 2014 р. 3 його особою пов'язують ряд скандалів щодо продажу краденого вугілля (Рідна 
якого в області відбулася значна зміна голів районних державних адміністрацій на представників пропрезидентських сил. Такі маніпуляції дозволили партії БПП «Солідарність» зміцнити свої позиції в регіоні.

Новий період формування/оновлення регіональної політичної еліти Львівщини пов'язаний 3 О. Синюткою амбітним i досвідченим політиком, який спочатку використовував ресурс i впливи в області А. Садового (тривалий час він був його заступником у Львівській міській раді), а згодом - і у боротьбі проти останнього. Послужний список О. Синютки, включаючи участь у комерційній діяльності, у роботі органів місцевого самоврядування ІваноФранківська та Львова свідчив, що він був досвідченим управлінцем, однак не «самостійним політичним гравцем». Його призначення цілком могло носити практичне значення для центральної влади. Зокрема, спираючись на авторитет мера Львова можна було посприяти зміцненню в регіоні позицій пропрезидентських сил, що, у свою чергу, передбачало як усунення політичних конкурентів, так і послаблення колишніх союзників (Яремчук, 2018).

О. Синютка відпрацював на посаді голови облдержадміністрації протягом п’яти років, що було найдовшим в історії області періодом перебування на цій посаді, а в липні 2019 р. указом президента В. Зеленського на посаду було призначено М. Мальського. Натомість О. Синютка був обраний по списку партії «Свропейська Солідарність» народним депутатом Верховної Ради IX скликання (Радь, 2019). Щодо кандидатури М. Мальського, відомо, що спочатку він відмовлявся від пропозицій очолити ОДА, однак згодом все ж

фірма екс-голови ЛОДА не сплачує ПДВ і продає вугілля невідомого походження), зв'язків зі злочинною діяльністю сина екс-генпрокурора В. Пшонки, а також мільярдера С. Курченка (Курченко з Пшонкою наслідили у Львові). Однак, заява пресслужби, яка міститься на сайті Львівської обласної державної адміністрації повністю спростовує причетність Ю. Турянського до подібного роду діяльності та вказує на безпідставність й необгрунтованість звинувачень на його адресу (Звинувачення на адресу Юрія Турянського - безпідставні та необгрунтовані). 
таки погодився. Президентом В. Зеленським при призначенні нового голови ОДА були задіяні нові - ззовні демократичні процедури - інтернет-голосування в мережі Facebook. Cеред кандидатів на посаду голови Львівської облдержадміністрації претендував також Д. Шмигаль, однак результати голосування змогли йому забезпечити лише третє місце. Однією з причин, яка викликала недовіру мешканці Львівщини були його зв'язки 3 Р. Ахметовим (2018-2019 рр. Д. Шмигаль був директором ДТЕК Бурштинська ТЕС та в.о. заступника генерального директора 3 соціальних питань ПАТ «ДТЕК Західенерго») (Зеленский в Facebook совещается, кого назначить председателем Львовской ОГА). Невдовзі, уже в грудні 2019 р., президент В. Зеленський звільнив і М. Мальського з посади голови ОДА, обгрунтувавши це відсутністю жодного результату (Президент звільнив Маркіяна Мальського з посади голови ЛОДА). За період перебування на посаді голови облдержадміністрації М. Мальського було призначено 17 iз 20 очільників РДА, які відбиралися за новим принципом, за допомогою спеціальної платформи LIFT (Зеленський призначив вже сімнадцятьох голів РДА на Львівщині).

На основі проаналізованого матеріалу підкреслимо, що високий показник оновлення рад $з$ одного боку, свідчить про невдоволення мешканців регіону політичною елітою та рівнем життя, який вони отримували при ній, а також про бажання до змін. А з іншого боку - очевидно, що представницькі органи області використовуються регіональною політичною елітою як стартовий майданчик для подальшого кар'єрного росту, що призводить до постійного руху та припливу нових обличь.

До неформальної еліти ми віднесли керівні групи суспільства, які впливають на прийняття рішень в регіоні, але при цьому можуть не обіймати посад в державному апараті та не займатися політикою безпосередньо. На Львівщині до неформальної еліти доцільно віднести бізнес-еліту, власників 3МI, лідерів злочинних угрупувань тощо.

Говорячи про загальну тенденцію, зауважимо, що бізнеселіта не лише має можливість, вона впливає на «прийняття 
політичних рішень» за рахунок концентрації економічних ресурсів. Завдяки наявності ресурсів бізнес $\epsilon$ не лише роботодавцем та наповнювачем державного бюджету, але й ініціатором багатьох проектів державного масштабу, що в результаті дає змогу ще більше зміцнити позиції та протистояти конкуренції. В цілому, необхідно говорити про такі характерні ознаки бізнес-еліти як складової політичного класу: безпосередня участь у законодавчій або виконавчій владі, можливість впливу на інформаційний простір завдяки медіаресурсу, що зосереджений у руках представників бізнес-еліти, дотримання соціальної поведінки в бізнесі, реалізація територіальних та загальнонаціональних соціальних програм, знання проблемних моментів діяльності економічних агентів та практичного досвіду їх подолання - 3 одного боку, та неконкурентне лобіювання власних інтересів в органах влади 3 іншого (Брехаря, 2010).

Процес формування бізнес-еліти Львівщини мало чим відрізнявся від загальнодержавних тенденцій та припав на 1990-ті pр. Окрім збагачення та процвітання, важливим завданням для представників бізнесу було домовитися з владою про забезпечення найбільш сприятливих умов для розвитку власних інтересів, що у свою чергу, призвело до корупційних схем, незаконних домовленостей та клієнтелізму.

Про «великий бізнес», який вирізняється стійкими позиціями в регіоні можна говорити, починаючи з 2000-х рр. Досить помітними в політичному житті Львівщини були фінансово-промислові групи, пов'язані 3 прізвищами С. Сенчука, П. Димінського, Б. та Я. Дубневичів, В. Антонова, Р. Федишина тощо.

Прізвище С. Сенчука***, перш за все асоціюють 3 *** У 2005 р. С. Сенчука було вбито на місці запланованої зустрічі з адвокатом
(Розстріляли екс-губернатора Львівщини). Серед версій вбивства з’являлися як
політичні, так і виключно бізнесові. Зокрема, серед політичних версій: 1) вбивство
С. Сенчука було вигідне опонентам НСНУ (який фінансував керівник «Еколану»)
на Львівщині; 2) можливе призначення на посаду керівника Держкомрезерву.
Бізнесові мотиви вбивства опиралися на надмірне зацікавлення С. Сенчуком
скандальним львівським ВАТ «Львівсільмаш» (Кому вигідне вбивство Cтепана 
концерном «Еколан». У політичних колах він відомий завдяки головуванню у Львівській обласній раді (1998-2001) та Львівській обласній державній адміністрації (1999-2001). Бізнесмен та політик неодноразово фігурував у низці скандалів, серед яких зловживання службовим становищем, протизаконна підприємницька діяльність (приватизація підприємств, які ввійшли в корпорацію «Еколан», житлових приміщень та виділення земельних ділянок під власні потреби). Окрім фактів, які вказують на пряме відношення С. Сенчука до політики, є ще непрямі докази можливого ним фінансування президентської кампанії В. Ющенка (Убитий екс-губернатор йшов у Київ на «хлібне місце»?).

Наступною відомою фігурою Львівщини, яка привертає увагу, є П. Димінський. Його бізнес включає нафтопереробну галузь (НПК «Галичина»), медіа бізнес (інформаційне агентство ZIK) та спорт (ФК «Карпати»). За версією журналу «Форбс» (рейтинг «100 найзаможніших українців») упродовж 2012-2016 pр. П. Димінський займав позиції з №91 по №44. Активна політична діяльність бізнесмена, який позиціонував себе як «непублічна особа», розпочалася в 2000-х рр., коли він співробітничав 3 низкою політичних партій, включаючи i надання їм фінансової допомоги (НРУ, блок «Наша Україна», ПОЛІТИЧНА ПАРТІЯ «ПАРТІЯ РЕГІОНІВ», ВО «Батьківщина», ВО «Свобода»), що дозволяло йому впливати на результати виборів до парламенту, органів місцевого самоврядування, на діяльність та кадрову політику Львівської облдержадміністрації. Особисто він був народним депутатом України IV скликання (2002-2005) - від політичної партії Блок Віктора Ющенка «Наша Україна». Наступна ж спроба

Сенчука?). Досить цікаво прокоментував вбивство екс-очільника Львівщини тодішній помічник народного депутата П. Димінського Ю. Шведа. Він зазначив, що відповідь на це питання варто шукати у плівках, оприлюднених гендиректором ФК «Карпати» Б. Федоришиним. На записах був компромат на голову Львівської ОДА П. Олійника. Невідомі голоси начебто викривали факти корупції в діяльності голови облдержадміністрації, зв'язки 3 С. Сенчуком та екс-начальником Західної регіональної митниці Т. Козаком (Кому вигідне вбивство Степана Сенчука?). 
отримати мандат депутата у 2006 р. через партію екологічного порятунку «ЕКО+25\%» (був під №9 у виборчому списку партії) виявилася невдалою, партія не набрала достатньої кількості голосів та не зуміла потрапити до Верховної Ради України.

Брати Дубневичі**** асоціюються 3 так званою «залізничною групою» та тісною співпрацею 3 колишнім Міністром транспорту та зв'язку України Г. Кірпою (2004р.). Довготривалий контракт з «Укрзалізницею» (ООО «Корпорація Колійні ремонтні технології» впровадження винаходу «кріплення шпали») стало інструментом як для збагачення ФПГ (фінансово-промислової групи), так i нав'язування зв'язків з політичною елітою країни. Досить помітною була взаємодія бізнесменів з такими політичними силами як ВО «Батьківщина», «Партія «Відродження», БПП «Солідарність». Тривалий час брати Дубневичі були головними «спонсорами» у Львівській області політичної партії ВО «Батьківщина» та провладної партії «Відродження» (Г. Кірпа). Існування потужної «групи Дубневичів» серед депутатського корпусу вказувало на повну підконтрольність їм обласної ради, обраної у 2015 р., де кожен третій депутат був вихідцем 3 Пустомитівського та Городоцького районів (саме там народилися, створили первинний бізнес АПК та почали політичну кар'єру Б. та Я. Дубневичі) ${ }^{1^{* * * * * *}}$ та й сам голова

**** Політична кар'єра братів Дубневичів розпочалася у 2000-х в політичній силі БЮТ. Ярослав навіть був заступником глави фракції цієї партії у Львівській обласній раді. Потім політична кон'юнктура змінилася, і у 2010 р. братів обрали до Львівської облради від партії «Відродження». У Верховну Раду VII скликання у 2012 р. вдалося пройти тільки Ярославу, який йшов на вибори як самовисуванець, але пізніше приєднався до фракції УДАР. У Верховній Раді VIII скликання обидва брати були членами фракції БПП «Солідарність» (Хто такий Ярослав Дубневич $і$ за щзо його позбавили недоторканості).

***** Про лобіювання власних інтересів братів Дубневичів в окремих районах Львівської області свідчать дані щодо фінансування інвестиційних програм та проектів саме в тих чотирьох районах (Пустомитівський, Городоцький, Самбірський та Мостиський), які були виборчими округами, на яких обрали Богдана та Ярослава Дубневичів народними депутатами від блоку БПП «Солідарність». Тричі поспіль ці райони отримували найбільше фінансування попри те, що тут проживає лише $12 \%$ населення області (Дубневичам на тацюю). 
Львівської обласної ради О. Ганущин, за інформацією окремих 3MI, також був наближеним до братів Дубневичів (Радь, 2019). Традиційно до найзаможніших підприємців Львівщини можна віднести також Р. Федишина (депутата Львівської міської ради від фракції «Самопоміч», якому належить 50,5\% від капіталу ТОВ «Шувар» - наймасштабнішого у Західному регіоні оптового ринку сільськогосподарської продукції) (Радь, 2019) та В. Антонова (засновника «ОKKO Group», голову наглядової ради «Концерну Галнафтогаз» ${ }^{* * * * * *}$, статки якого налічують 520 млн. дол. США). Щодо останнього, то з 2002 р. за підтримки М. Гладія (голови Львівської облдержадміністраціі) В. Антонов спробував зайнятися політикою (йдеться про членство у НДП та участь у виборах на допомогу політичного альянсу «За єдину Україну», а пізніше про підтримку давнього бізнес-партнера 3. Карпінського на виборах мера Стрия (Найбагатший львів'янин готовий переїхати у райцентр через вибори), проте ці спроби не увінчалися успіхом.

У цілому діяльність львівської бізнес-еліти була спрямована на всіляку співпрацю з владою або ж безпосередню їхню участь у політиці 3 можливістю отримати вплив на політичні рішення в регіоні, доступ до розподілу фінансових ресурсів та кадрових призначень на рівні місцевої влади.

Надаючи значення формуванню громадської думки, представники ФПГ стали помітними «гравцями» на медіаринку Львівської області. Так, провідні інформаційні ресурси в регіоні (передусім телерадіомовлення, Інтернет) входили до складу медіахолдингів, які очолювали П. Димінський (інформагенція ZIK («Західна інформаційна корпорація»),

\footnotetext{
****** У 2018 р. в офіси «Галнафтогазу» (мережі АЗС «ОККО») у Львові та Києві навідались працівники СБУ з обшуком. В. Антонова звинувачували у фінансуванні дій, спрямованих на повалення конституційного ладу та зміни державних кордонів України, фінансуванні сепаратизму на Донбасі, роботі мережі заправок в окупованому Криму. Бенефіціар концерну всі ці звинувачення спростував, а через кілька місяців Генпрокуратура закрила кримінальне провадження у справі (Радь, 2019).
} 
телеканал ZIK), Б. і Я. Дубневичі («Львівська газета», радіо «FM Галичина», телекомпанія Гал-ТБ, Інтернет-сайт Galnet.org), А. Садовий, а точніше його дружина Катерина КітСадова, яка є бенефіціарним власником ТРК «Люкс» (яка включає «24 канал», радіо «Lux FM», інтернет-видання Zaxid.net, радіо «Максимум», сайт Football 24) та рекламне агентство «Люкс» (Політична карта Львівської області; Онисько, 2013).

Проблема організованої злочинності набула актуального значення для Львівщини починаючи з 1990-х рр. Як і на решті території країни, масова приватизація посприяла зростанню рекету, контрабанди, поширеним явищем стала торгівля наркотичними засобами та краденими автомобілями. I хоча до кінця 1990-х рр. діями силових структур держави 3 організованою злочинністю як суспільним явищем було покінчено, в області і надалі з високою інтенсивністю тривали процеси, пов'язані з незаконною підприємницькою діяльністю, перерозподілом сфер впливу та власності, рейдерськими захопленнями, замовними вбивствами (Яремчук, 2018). Іншим боком існування явища організованої злочинності стало іiі поступове проникнення в політику, що головним чином проявлялося через поодиноке «просочування» «колишніх» кримінальних авторитетів як «бізнесменів» чи «політиків» до складу органів місцевого самоврядування (районних, міських, обласної ради) та навіть Верховної Ради України (Яремчук, 2018).

Яскравим прикладом зв'язків кримінального світу 3 політикою може послугувати історія «білявки в законі» Л. Софієнко. Показово, що її прізвище на початку 1990-х рр. часто фігурувало в кримінальних справах, відомими були факти їі причетності до злочинних угрупувань, які займалися рекетом. Проте починаючи з 2000-х рр. Л. Софієнко стає відома як власниця міжнародного бізнесу в аграрній та енергетичній сферах. Як можна прослідкувати з ії̈ біографічної довідки, таке процвітання бізнесу, не в останню чергу, відбулося завдяки 
чоловіку Л. Софієнко екс-регіоналу - В. Пехову (помічнику міністра аграрної політики та продовольства часів експрезидента В. Януковича, міністра М. Присяжнюка) (Бандитський Львів: історія «білявки в законі» Лесі Софієнко). Ще одним способом отримання колишніми кримінальними авторитетами певних гарантій та безпеки було членство в політичних партіях та їх фінансування. Після перемоги Революції Гідності розголосу набуло оприлюднення викривальних матеріалів щодо зв'язків 3 кримінальним світом ВО «Свобода» (Починок, 2014). Саме тоді львівський бізнесмен В. Дідух (відомий як кримінальний авторитет В. Морда) заявив, що дав нардепу від $\mathrm{BO}$ «Свобода» I. Кривецькому 48 млн. дол. США на утримання осередків партії, організацію мітингів та зарплату працівникам, а також, що саме він допоміг політичній партії «народитися» (Вова Морда: Я дав «Свободі» \$ 48 мільйонів, вони брали у всіх). Поява такої інформації в ЗМІ стала однією з причин стрімкого падіння рейтингу партії як на Львівщині, так і в країні в цілому.

Щодо кількісної оцінки політичної еліти Львівщини, важко говорити про конкретні цифри. Оскільки до цієї категорії можна віднести як відносно невелику когорту осіб (від кількох сотень), які контролюють більшість ресурсів, нав'язали міцні зв'язки на регіональному та загальнодержавному рівнях та мають безсумнівний вплив на прийняття політичних рішень, так і значно розшити ії кількістю осіб (до тисячі двохсот), серед яких найвпливовіші політики (народні депутати України), очільники та депутати місцевих рад, керівництво ОДА та іï департаментів, голови регіональних організацій політичних партій та основні неформальні лідери в регіоні. Такий показник ми отримали, підрахувавши кількісний склад усіх рад регіону та додавши до них неформальних лідерів, які приймають або потенційно можуть впливати на прийняття політичних рішень у Львівській області.

Висновки та перспективи подальших розвідок. Підсумовуючи, зазначимо, що регіональну політичну еліту 
Львівщини ми класифікували, поділивши іiі на дві основні групи: формальну (еліта, яка обіймає певні посади у владній вертикалі та приймає політичні рішення) та неформальну (еліта, яка не бере безпосередньої участі у політиці, але наділена потужними ресурсами, щоб впливати на процес прийняття політичних рішень). Відтак, основними шляхами приходу до влади формальної регіональної політичної еліти Львівщини є обрання або призначення на посади в органи законодавчої та виконавчої влади. Щодо неформально еліти, то ii участь у політичному житті регіону забезпечувалася наявними ресурсами: економічними, родинними та бізнесовими зв' язками, доступом до засобів масової інформації та причетністю до злочинних угрупувань.

Процес оновлення львівської формальної регіональної політичної еліти розпочався в 1990-х рр. (що уже тоді свідчило про зародження у регіоні демократичних процесів й перехід до багатопартійності) та триває досі. Однак, про більш демократичну та прозору природу оновлення еліти можна говорити під час виборів (до Верховної Ради України, місцевих рад), натомість іiі оновлення в органах державної влади (призначення керівників ОДА, РДА) відображає загальнодержавні тенденції. Закономірним є наявність того факту, що кожна нова загальнонаціональна політична сила, що приходить до влади намагається встановити/посилити свій контроль над суспільно-політичним життям області, при необхідності налагоджуючи патрон-клієнтальні зв'язки 3 місцевою елітою, що до певної міри свідчить про незавершений процес становлення регіональної політичної еліти Львівщини.

Стосовно неформальної еліти, проаналізований матеріал дозволив дійти висновку, що ця категорія еліти завдяки наявним ресурсам дійсно здійснює вплив на політичний процес регіону. Найбільш потужною групою неформальної еліти можна вважати бізнес-еліту, яка окрім фінансових важелів впливу часто використовує також маніпулювання громадською 
думкою через доступ до медіа-ресурсів. Формування основного бізнес-середовища Львівщини відбувалося в період з к. 1990-х до поч. 2000 рр. Одним із першочергових завдань, яке переслідували представники бізнесу полягало в укладанні домовленостей 3 владою щодо забезпечення найбільш сприятливих умов для розвитку власних інтересів.

Зазначимо, що оновлення неформальної еліти проходить досить повільно. Входження до цієї категорії «нових облич» відбувається значно рідше, ніж в групі формальної політичної еліти. Кількісні зміни в добре сформованих кланах, якщо й відбуваються, то лише шляхом прийняття «своїх» людей.

\section{ДЖЕРЕЛА ТА ЛІТЕРАТУРА}

1. СтопКор. (2019, 8 січня). Бандитський Львів: історія «білявки в законі» Лесі Софієнко. URL: https://stopcor.org/ bbandytskyi-lviv-istoriya-bilyavki-v-zakoni-lesi-sofiyenko/

2. Брехаря, С. (2010). Бізнес-еліта в сучасній Україні: засоби впливу на політичний процес. Наукові записки Інституту політичних і етнонаціональних досліджень ім. І. Ф. Кураса НАН Украӥни, Вип. 1. 100-110. URL: https://ipiend.gov.ua/wpcontent/uploads/2018/07/breharia_biznes_elita.pdf

3. Буковский, Д. (2015, 25 листопада). Новые феодальл: как разделилась страна после выборов. URL: http:// www.dsnews.ua/ politics/ novye-feodaly-kak-razdelilas-stranaposlevyborov-28112015102100

4. Українська правда. (2014, 13 листопада). Вова Морда: Я дав «Свободі» \$48 мільйонів, вони брали у всіх. URL: https://www.youtube.com/watch?v=iI9-m2vjQ_Q

5. 20 хвилин. (2014, 28 лютого). Гройсману крісло вічепрем'єра запропонували після того, як від нього відмовився Садовий. URL: https://vn.20minut.ua/Podii/groysmanu-krislovitsepremera-zaproponuvali-pislya-togo-yak-vid-nogo-10318330. html 
6. ZAXID. NET. (2017, 14 червня). Дубневичам на таџңю. URL: https://zaxid.net/dubnevicham_na_tatsyu_n1428516

7. УкрЗахідІнформ. (2014, 2 листопада). Звинувачення на адресу Юрія Турянського - безпідставні та необгрунтовані. URL: https://loda.gov.ua/news?id=13942

8. Укрінформ. (2019, 14 червня). Зеленский в Facebook совещуается, кого назначить председателем Львовской ОГА. URL: https://www.ukrinform.ru/rubric-regions/2721715-zelenskijv-facebook-sovesaetsa-kogo-naznacit-predsedatelem-lvovskoj-oga. html

9. Львівський портал. (2019, 18 грудня). Зеленський призначив вже сімнадиятьох голів РДА на Львівщині. URL: https:/portal.lviv.ua/news/2019/12/18/zelenskyj-pryznachyv-vzhesimnadtsiatokh-holiv-rda-na-lvivshchyni

10. Львівський портал. (2005, 30 листопада). Кому вигідне вбивство Степана Сенчука? URL: https:/portal.lviv.ua/ article/2005/11/30/123723

11. ZAXID. NET. (2014, 31 жовтня). Курченко з Пшонкою наслідили у Львові. URL: https://zaxid.net/kurchenko_z_ pshonkoyu_naslidili_u_lvovi_n1328466

12. ОПОРА. Львів. (2011, 1 лютого). Львівська міська рада: хто в домі господар? URL: https://opora.lviv.ua/lvivska-miskarada-hto-v-domi-hospodar/

13. Маркітантов, В. (2009). Регіональна політична еліта Львівщини: тенденції розвитку. Українська національна ідея: реалї та перспективи розвитку, випуск 21. 128-132. URL: http://vlp.com.ua/files/26_47.pdf

14. ZAXID. NET. (2015, 17 жовтня). Найбагатший львів'янин готовий переїхати у райцентр через вибори. URL: https://zaxid.net/naybagatshiy_lvivyanin_gotoviy_pereyihati_u_ray tsentr_cherez_vibori_n1369564

15. Офіційний веб-сайт Верховної Ради України. Народні Депутати Украӥни 1-го скликання (1990-1994). Верховна Рада України. URL: http://static.rada.gov.ua/zakon/new/ NEWSAIT/ DEPUTAT1/spisok1.htm. 
16. Офіційний веб-сайт Верховної Ради України. Народні депутати Украӥни 2-го скликання (1994-1998). Верховна Рада України. URL: http:/gska2.rada.gov.ua/pls/ radac_gs09/ $\mathrm{d}$ index arh?skl=2\#\%C0.

17. Офіційний веб-сайт Верховної Ради України. Народні Депутати України 3-го скликання (1998-2002). Верховна Рада України. URL: http:/gska2.rada.gov.ua/ pls/radac_gs09/ d_index_arh?skl=3.

18. Офіційний веб-сайт Верховної Ради України. Народні депутати Украӥни. Верховна Рада України. URL: http://w1.c1.rada.gov.ua/pls/site2/p_deputat_list.

19. Онисько, Н. (2013, 29 серпня). Кому належать львівські 3MI. Hami гроші. Львів. URL: http:// lviv.nashigroshi.org/2013/08/29/komu-nalezhat-lvivski-zmi/

20. П'єцух, М. (2016, 29 червня). Відсидітися у ратуші. Як Садовий загнав себе в пастку. Украӥнська правда. URL: http://www.pravda.com.ua/articles/2016/06/29/7113126/

21. Сайт Центральної виборчої комісії. Чергові місиеві вибори 25 жовтня 2015 p. URL: https:// www.cvk.gov.ua/pls/vm2015/pvm057pid112 $=12$ pid102 $=2962$ pf76 $91=2962$ pt001f01 $=100$ rej=0pt00_t001f01 $=100$. html

22. Інформаційний портал депутатів Львівської міської ради. Підраховано автором на основі даних Львівської міської ради. URL: https://www.lvivrada.gov.ua/deputaty/deputaty-miskoi-rady

23. Сайт Центральної виборчої комісії. Позачергові вибори народних депутатів України. 2014. URL: http:// www. cvk.gov.ua/pls/vnd2014/wp302?PT001F01=- 910\&pf7171=185

24. ОПОРА. Політична карта Львівської області. URL: https://www.oporaua.org/vybory/politychni-karty-oblastei2014/4691-5015- 1446980692-politychna-karta-lvivskoji-oblasti

25. Починок, I. (2014, 23 жовтня). Справжній господар nартіi «Свобода». URL: http://expres.ua/ main/ 2014/10/23/117377-spravzhniy-gospodar-partiyi-cvoboda 120.

26. Твоє місто. (2019, 24 грудня). Президент звільнив Маркіяна Мальського з посади голови ЛОДА. URL: 
http://tvoemisto.tv/news/prezydent_zvilnyv_markiyana_malskogo_ z_posady_golovy_loda_105379.html

27. Радь, Т. (2019, 29 листопада). Політична карта Львівської області. ОПОРА. URL: https://www.oporaua.org/ article/vybory/ parlamentski-vybory/ political_map19/19540-politichna-kartalvivskoyi-oblasti

28. Наші гроші Львів. (2015, 17 квітня). Рідна фірма ексголови ЛОДА не сплачує ПДВ $і$ продає вугілля невідомого походження. URL: http://viv.nashigroshi.org/2015/04/17/firmakolyshnoho-holovy-loda-ne-splachuje-pdv-i-prodaje-vuhillya-nevid omoho-pohodzhennya/

29. Українська правда. (2005, 29 листопада). Розстріляли ексгубернатора Львівщчини. URL: https://www.pravda.com.ua/ news/2005/11/29/3024643/

30. PolitHub. Org. Садовий Андрій Іванович. Львівська міська рада - голова 6, РХП, Міський голова Львова. URL: https://www.chesno.org/politician/25963/

31. Тузяк, Н. (2019, 23 липня). Зроблені у Львові. Дивіться, хто пройшов у Верховну Раду! ZAXID. NET. URL: https://zaxid.net/zrobleni_u_lvovi_n1485826

32. Українська правда. (2005, 30 листопада). Убитий ексгубернатор ймов у Київ на «хлібне місие»? URL: https://www.pravda.com.ua/news/2005/11/30/3025091/

33. 032. Сайт міста Львова. (2019, 3 травня). Хто керував Львовом упродовж останніх 28 років: ретроспектива. URL: https://www.032.ua/news/2383279/hto-keruvav-lvovom-uprodovzostannih-28-rokiv-retrospektiva

34. Львівський портал. (2015, 28 жовтня). Хто став депутатами Львівської обласної ради VII скликання. URL: https://portal.lviv.ua/news/2015/10/28/hto-stav-deputatamilvivskoyi-oblasnoyi-radi-vii-sklikannya-onovlyuyetsya

35. Головне. (2019, 2 листопада). Хто такий Ярослав Дубневич $і$ за що його позбавили недоторканості. URL: https:// gordonua.com/ukr/publications/-hto-takij-jaroslav-dubnevich-i-zashcho-jogo-pozbavili-nedotorkannosti-golovne-1392576.html 
36. Українська правда. (2013, 31 жовтня). Янукович призначив на Львівщину губернатора, якого шукали за фальсифікації. URL: https://www.pravda.com.ua/news/2013/10/31/7001117/

37. Яремчук, В. (2018). Регіональні політичні режими в Україні: Львівщина (1990-2017 рр.). ІПіЕНД ім. І. Ф. Кураса НАН України.

\section{REFERENCES}

1. StopKor (2019, 8 sichnia). Bandytskyi Lviv: istoriia «biliavky $v$ zakoni» Lesi Sofiienko [Bandit Lviv: the story of «blonde in law» Lesya Sofienko]. Retrieved from: https://stopcor.org/bbandytskyilviv-istoriya-bilyavki-v-zakoni-lesi-sofiyenko/ [in Ukrainian].

2. BREHARJA, S. (2010). Biznes-elita v suchasnii Ukraini: zasoby vplyvu na politychnyi protses [Business elite in modern Ukraine: means of influencing the political process]. Naukovi zapysky Instytutu politychnykh i etnonatsionalnykh doslidzhen im. I. F. Kurasa NAN Ukrainy, Vyp. 1. 100-110. Retrieved from: https://ipiend.gov.ua/wpcontent/uploads/2018/07/breharia_biznes_elita.pdf [in Ukrainian].

3. BUKOVSKYJ, D. (2015, 25 lystopada). Novye feodaly: kak razdelilas'strana posle vyborov [New feudal lords: how the country was divided after the elections]. Retrieved from: http:// www.dsnews.ua/politics/ novye-feodaly-kak-razdelilas-stranaposlevyborov-28112015102100 [in Ukrainian].

4. Ukrainska pravda. (2014, 13 lystopada). Vova Morda: Ya dav «Svobodi»\$ 48 milioniv, vony braly u vsikh [Vova Morda: I gave «Svoboda» \$ 48 million, they took the stench from everyone]. Retrieved from: https://www.youtube.com/watch?v=iI9-m2vjQ_Q [in Ukrainian].

5. 20 khvylyn. (2014, 28 liutoho). Hroismanu krislo vitsepremiera zaproponuvaly pislia toho, yak vid noho vidmovyvsia Sadovyi [Groysman was offered the post of deputy prime minister after Sadovy refused]. Retrieved from: https:// vn.20minut.ua/ Podii/groysmanu-krislo-vitsepremera-zaproponuvali-pislya-togoyak-vid-nogo-10318330.html [in Ukrainian]. 
6. ZAXID. NET. (2017, 14 chervnia). Dubnevycham na tatsiu. [Dubnevich on a tray]. Retrieved from: https://zaxid.net/ dubnevicham_na_tatsyu_n1428516

7. UkrZakhidInform. (2014, 2 lystopada). Zvynuvachennia na adresu Yuriia Turianskoho - bezpidstavni ta neobhruntovani [The accusations against Yuriy Turyansky are baseless and unfounded]. Retrieved from: https://loda.gov.ua/news?id=13942 [in Ukrainian].

8. Ukrinform. (2019, 14 chervnia). Zelenskyi v Facebook soveshchaetsia, koho naznachyt predsedatelem Lvovskoi OHA [Zelensky on Facebook confers who to appoint the chairman of the Lviv Regional State Administration]. Retrieved from: https:// www.ukrinform.ru/ rubric-regions/2721715-zelenskij-v-facebooksovesaetsa-kogo-naznacit-predsedatelem-lvovskoj-oga.html [in Ukrainian].

9. Lvivskyi portal. (2019, 18 hrudnia). Zelenskyi pryznachyv vzhe simnadtsiatokh holiv RDA na Lvivshchyni [Zelensky has already appointed seventeen heads of regional state administrations in the Lviv region]. Retrieved from: https://portal.lviv.ua/ news/ 2019/12/18/ zelenskyj-pryznachyv-vzhe-simnadtsiatokh-holiv-rdana-lvivshchyni [in Ukrainian].

10. Lvivskyi portal. (2005, 30 lystopada). Komu vyhidne vbyvstvo Stepana Senchuka? [Who benefits from the murder of Stepan Senchuk?] Retrieved from: https://portal.lviv.ua/ article/2005/11/30/123723 [in Ukrainian].

11. ZAXID. NET. (2014, 31 zhovtnia). Kurchenko z Pshonkoiu naslidyly u Lvovi [Kurchenko and Pshonka inherited in Lviv]. Retrieved from: https://zaxid.net/kurchenko_z_ pshonkoyu_ naslidili_u_lvovi_n1328466 [in Ukrainian].

12. OPORA. Lviv. (2011, 1 liutoho). Lvivska miska rada: khto $v$ domi hospodar? [Lviv City Council: who is the owner of the house?] Retrieved from: https://opora.lviv.ua/lvivska-miska-radahto-v-domi-hospodar/ [in Ukrainian].

13. MARKITANTOV, V. (2009). Rehionalna politychna elita Lvivshchyny: tendentsii rozvytku [Regional political elite of Lviv region: development trend]. Ukrainska natsionalna ideia: realii ta 
perspektyvy rozvytku, vypusk 21. 128-132. Retrieved from: http://vlp.com.ua/files/26_47.pdf [in Ukrainian].

14. ZAXID. NET. (2015, 17 zhovtnia). Naibahatshyi lvivianyn hotovyi pereikhaty $u$ raitsentr cherez vybory [The richest Lviv resident is ready to move to the district center due to the elections]. Retrieved from: https:/zaxid.net/ naybagatshiy_ lvivyanin gotoviy_pereyihati_u_raytsentr_cherez_vibori_n1369564 [in Ukrainian].

15. Ofitsiinyi veb-sait Verkhovnoi Rady Ukrainy. Narodni Deputaty Ukrainy 1-ho sklykannia (1990-1994). Verkhovna Rada Ukrainy [Deputies of Ukraine of the 1st convocation (1990-1994). Verkhovna Rada of Ukraine]. Retrieved from: http:// static.rada.gov.ua/zakon/new/ NEWSAIT/DEPUTAT1/spisok1.htm [in Ukrainian].

16. Ofitsiinyi veb-sait Verkhovnoi Rady Ukrainy. Narodni deputaty Ukrainy 2-ho sklykannia (1994-1998). Verkhovna Rada Ukrainy [Deputies of Ukraine of the 2nd convocation (19941998). Verkhovna Rada of Ukraine]. Retrieved from: http://gska2.rada.gov.ua/pls/radac_gs09/d_index_arh?skl=2\#\%C0 [in Ukrainian].

17. Ofitsiinyi veb-sait Verkhovnoi Rady Ukrainy. Narodni Deputaty Ukrainy 3-ho sklykannia (1998-2002). Verkhovna Rada Ukrainy [Deputies of Ukraine of the 3rd convocation (1998-2002). Verkhovna Rada of Ukraine]. Retrieved from: http:// gska2.rada.gov.ua/ pls/ radac_gs09/ d_index_arh?skl=3 [in Ukrainian].

18. Ofitsiinyi veb-sait Verkhovnoi Rady Ukrainy. Narodni deputaty Ukrainy. Verkhovna Rada Ukrainy [Deputies of Ukraine. Verkhovna Rada of Ukraine]. Retrieved from: http://w1.c1.rada.gov.ua/pls/site2/p_deputat_list [in Ukrainian].

19. ONYS'KO, N. (2013, 29 serpnia). Komu nalezhat lvivski ZMI. [Who owns the Lviv media]. Nashi hroshi. Lviv. Retrieved from: http://lviv.nashigroshi.org/2013/08/29/komu-nalezhat-lvivskizmi/ [in Ukrainian]. 
20. P'JECUH, M. (2016, 29 chervnia). Vidsyditysia u ratushi. Yak Sadovyi zahnav sebe v pastku [Sit in the town hall. How Sadovy drove himself into a trap]. Ukrainska pravda. Retrieved from: http://www.pravda.com.ua/articles/2016/06/29/7113126/ [in Ukrainian].

21. Sait Tsentralnoi vyborchoi komisii. Cherhovi mistsevi vybory 25 zhovtnia $2015 r$. [Regular local elections on October 25, 2015]. Retrieved from: https://www.cvk.gov.ua/ pls/vm2015/ pvm057pid112 $=12$ pid102 $=2962$ pf $7691=2962$ pt001 f01 $=100 \mathrm{rej}=0 \mathrm{pt}$ 00_t001f01 $=100 . \mathrm{html}$ [in Ukrainian].

22. Informatsiinyi portal deputativ Lvivskoi miskoi rady. Pidrakhovano avtorom na osnovi danykh Lvivskoi miskoi rady [Calculated by the author based on data from the Lviv City Council]. Retrieved from: https://www.lvivrada.gov.ua/ deputaty/deputaty-miskoi-rady [in Ukrainian].

23. Sait Tsentralnoi vyborchoi komisii. Pozacherhovi vybory narodnykh deputativ Ukrainy. 2014 [Extraordinary elections of people's deputies of Ukraine. 2014]. Retrieved from: http://www.cvk.gov.ua/pls/vnd2014/wp302?PT001F01=910\&pf7171=185 [in Ukrainian].

24. OPORA. Politychna karta Lvivskoi oblasti [Political map of Lviv region]. Retrieved from: https://www.oporaua.org/ vybory/politychni-karty-oblastei-2014/4691-5015- 1446980692politychna-karta-lvivskoji-oblasti [in Ukrainian].

25. POCHYNOK, I. (2014, 23 zhovtnia). Spravzhnii hospodar partii «Svoboda» [The real owner of the party «Svoboda»]. Retrieved from: http://expres.ua/main/2014/10/23/117377spravzhniy-gospodar-partiyi-cvoboda 120 [in Ukrainian].

26. Tvoie misto. (2019, 24 hrudnia). Prezydent zvilnyv Markiiana Malskoho z posady holovy LODA [The President dismissed Markiyan Malsky from the post of LODA chairman]. Retrieved from: http://tvoemisto.tv/news/ prezydent_zvilnyv_markiyana_ malskogo_z_posady_golovy_loda_105379.html [in Ukrainian].

27. RAD', T. (2019, 29 lystopada). Politychna karta Lvivskoi oblasti [Political map of Lviv region]. OPORA. Retrieved from: 
https:// www.oporaua.org/article/vybory/parlamentski-vybory/ political_map19/ 19540-politichna-karta-lvivskoyi-oblasti [in Ukrainian].

28. Nashi hroshi Lviv. (2015, 17 kvitnia). Ridna firma eks-holovy LODA ne splachuie PDV $i$ prodaie vuhillia nevidomoho pokhodzhennia [The former firm of the ex-chairman of LODA does not pay VAT and sells coal of unknown origin]. Retrieved from: http://lviv.nashigroshi.org/2015/04/17/firma-kolyshnoho-holovyloda-ne-splachuje-pdv-i-prodaje-vuhillya-nevidomoho-pohodzhenn ya/ [in Ukrainian].

29. Ukrainska pravda. (2005, 29 lystopada). Rozstrilialy ekshubernatora Lvivshchyny [The ex-governor of Lviv region was shot]. Retrieved from: https:/www.pravda.com.ua/ news/2005/11/29/3024643/ [in Ukrainian].

30. PolitHub. Org. Sadovyi Andrii Ivanovych. Lvivska miska rada - holova 6, RKhP, Miskyi holova Lvova [Sadovy Andriy Ivanovych, Lviv City Council - Chairman 6, RHP, Mayor of Lviv]. Retrieved from: https://www.chesno.org/politician/25963/ [in Ukrainian].

31. TUZJAK, N. (2019, 23 lypnia). Zrobleni u Lvovi. Dyvitsia, khto proishov u Verkhovnu Radu! [Made in Lviv. Look who went to the Verkhovna Rada!]. ZAXID. NET. Retrieved from: https://zaxid.net/zrobleni_u_lvovi_n1485826 [in Ukrainian].

32. Ukrainska pravda. (2005, 30 lystopada). Ubytyi ekshubernator yshov u Kyiv na «khlibne mistse»? [The murdered ex-governor went to Kyiv for a «bread place»?]. Retrieved from: https://www.pravda.com.ua/ news/2005/11/30/3025091/ [in Ukrainian].

33. 032. Sait mista Lvova. (2019, 3 travnia). Khto keruvav Lvovom uprodovzh ostannikh 28 rokiv: retrospektyva [Who has ruled Lviv for the last 28 years: a retrospective]. Retrieved from: https://www.032.ua/news/2383279/hto-keruvav-lvovom-uprodovzostannih-28-rokiv-retrospektiva [in Ukrainian].

34. Lvivskyi portal. (2015, 28 zhovtnia). Khto stav deputatamy Lvivskoi oblasnoi rady VII sklykannia [Who became deputies of the Lviv regional council of the VII convocation]. Retrieved from: 
https:// portal.lviv.ua/ news/ 2015/10/28/hto-stav-deputatamilvivskoyi-oblasnoyi-radi-vii-sklikannya-onovlyuyetsya

[in Ukrainian].

35. Holovne. (2019, 2 lystopada). Khto takyi Yaroslav Dubnevych $i$ za shcho yoho pozbavyly nedotorkanosti [Who is Yaroslav Dubnevych and why he was deprived of immunity]. Retrieved from: https://gordonua.com/ukr/publications/-hto-takij-jaroslavdubnevich-i-za-shcho-jogo-pozbavili-nedotorkannosti-golovne-139 2576.html [in Ukrainian].

36. Ukrainska pravda. (2013, 31 zhovtnia). Yanukovych pryznachyv na Lvivshchynu hubernatora, yakoho shukaly za falsyfikatsii [Yanukovych appointed a governor to Lviv region, who was wanted for falsifications]. Retrieved from: https:// www.pravda.com.ua/ news/2013/10/31/7001117/ [in Ukrainian].

37. JAREMCHUK,V. (2018). Rehionalni politychni rezhymy $v$ Ukraini: Lvivshchyna (1990-2017 rr.) [Regional political regimes in Ukraine: Lviv region (1990-2017)]. IPiEND im. I. F. Kurasa NAN Ukrainy. Retrieved from: https://ipiend.gov.ua/wp-content/ uploads/2018/09/regional_political_regime.pdf [in Ukrainian].

\section{АНОТАЦІЯ}

У статті досліджено особливості становлення регіональної політичної еліти Львівщини у період з 1990 р. до 2019 р. Основну увагу зосереджено на трьох завданнях: кого варто відносити до категорії «політичної еліти» Львівщцини; які основні шляхи ї формування, починаючи з періоду становлення України як держави і до сучасного етапу; якою $\epsilon$ кількісна оцінка політичної еліти Львівщини.

Зокрема, було визначено, кого варто вважати політичною елітою регіону. За допомогою, використаного у дослідженні, методу позичійного аналізу, було класифіковано регіональну політичну еліту на формальну та неформальну. Визначено, що формальна політична еліта займає певні посади y владній вертикалі, щзо формалізуе ї̈ причетність до прийняття політичних рішень. Натомість неформальна еліта 
представлена особами, які не займаючи керівних посад, формують певний тип відносин з масами, посідають вагоме місие у процесі прийняття важливих рішень та впливають на здійснення політичної влади в регіоні завдяки ресурсам, якими вони володіють (фінансовий капітал, авторитет, доступ до формування суспільної думки та маніпулювання нею тощуо).

Проаналізовано процес оновлення львівської формальної політичної еліти починаючи з 1990 р. та виявлено, щзо саме в цей період у регіоні спостерігаються зародки демократичних проиесів та перехід до багатопартійності. Помічено, щзо досить часто регіональна політична еліта Львівщчини використовувала представницькі органи області як стартовий майданчик для подальшого кар'єрного росту, щуо призводило до постійного руху та припливу нових обличь.

Досліджено, шуо серед неформальної політичної еліти найбільш потужною групою можна вважати бізнес-еліту, яка окрім фінансових важелів впливу часто використовує також маніпулювання громадською думкою через доступ до медіаресурсів. Відзначено, щуо оновлення в чій групі еліти відбувається значно повільніше, ніж серед формальної політичної еліти.

Окремо йдеться про кількісну оцінку регіональної політичної еліти Львівщини. Оскільки про конкретні кількісні підрахунки говорити важко, зазначено, шуо до иієї категорії можна віднести як відносно невелику когорту осіб (від кількох сотень), які контролюють більшість ресурсів та нав'язали міцні зв'язки на регіональному та загальнодержавному рівнях, так $і$ значно розширити ї̈ кількістю осіб (до тисячі двохсот), серед яких найвпливовіші політики (народні депутати України), очільники та депутати місцевих рад, керівництво ОДА та ї̈ департаментів, голови регіональних організацій політичних партій та основні неформальні лідери в регіоні.

Ключові слова: регіональна політична еліта, народні депутати, Львівська обласна державна адміністраџія, Львівська обласна рада, Львівська міська рада, політичні партї, бізнес-еліта, медіа-ресурси. 


\section{АННОТАЦИЯ}

B cmambе исследовань особенности становления региональной политической элиты Львовщчины в период с 1990 2. по 2019 г. Основное внимание было сосредоточено на трех задачах: кого следует относить к категории «политической элиты» Львовизины; какие основные пути ее формирования, начиная с периода становления Украины как государства и к современному этапу; какова количественная оценка политической элиты Львовицины.

В частности, было выявлено, кого следует считать политической элитой региона. С помощуью, использованного в исследовании, метода позицчионного анализа, региональная политическая элита классифицирована на формальную и неформальную. Определено, что формальная политическая элита занимает определенные долэнности во властной вертикали, что формализует ее причастность к принятию политических решений. Неформальная элита жсе представлена лицамии, которые не занимая руководячиих должнностей, формируют определенный тип отношений с массами, занимают значительное место в процессе принятия важных решений и влияют на осущзествление политической власти в регионе благодаря ресурсам, которьми они владеют (финансовый капитал, авторитет, доступ к формированию обиественного мнения, манипулирования им и т.д.).

В результате анализа процесса обновления львовской формальной политической элиты начиная с 1990 г., было установлено, что именно в этот период в регионе наблюдались зарождение демократических процессов и переход к многопартийности. Замечено, что довольно часто региональная политическая элита Львовшцины использовала представительнье органь области как стартовую площзадку для дальнеймего карьерного роста, что приводило к постоянному притоку новых лиц.

Отмечено, что среди неформальной политической элиты наиболее моияной группой выступает бизнес-элита, которая 
кроме финансовых рычагов влияния часто использует также манипулирования общественным мнением через доступ к медиа-ресурсам. На основании анализа, было установлено, что обновление в этой группе элиты происходит значительно медленнее, чем в среде формальной политической элиты.

B cтатье значительное внимание уделяется количественной оченке региональной политической элить Львовщины. Поскольку о конкретных количественные подсчеты говорить трудно, указано, что к этой категории можно отнести как относительно небольшую когорту лии (от нескольких сотен), которые контролируют большинство ресурсов и навязали крепкие связи на региональном и общегосударственном уровнях, так и значительно расширить ее количеством человек (до тысячи двухсот), среди которых самыле влиятельные политики (народные депутатьл Украины), руководители и депутаты местных советов, руководство ОГА $u$ ее департаментов, главы региональных организаций политических партий и основные неформальные лидеры в регионе.

Ключевые слова: региональная политическая элита, народные депутаты, Львовская областная государственная администрация, Львовский областной совет, Львовский городской совет, политические партии, бизнес-элита, медиаpecypcbl. 